\title{
How children talk about a conversation*
}

\author{
ASLI ÖZYÜREK
}

The University of Chicago

(Received I September 1994. Revised I3 February 1996)

\section{A BSTRACT}

This study investigates how children of different ages talk about a conversation that they have witnessed. 48 Turkish children, five, nine and thirteen years in age, saw a televised dialogue between two Sesame Street characters (Bert and Ernie). Afterward, they narrated what they had seen and heard. Their reports were analysed for the development of linguistic devices used to orient their listeners to the relevant properties of a conversational exchange. Each utterance in the child's narrative was analysed as to its conversational role: (I) whether the child used direct or indirect quotation frames; (2) whether the child marked the boundaries of conversational turns using speakers' names and (3) whether the child used a marker for pairing of utterances made by different speakers (agreement-disagreement, request-refusal, questioning-answering). Within pairings, children's use of (a) the temporal and evaluative connectivity markers and (b) the kind of verb of saying were identified. The data indicate that there is a developmental change in children's ability to use appropriate linguistic means to orient their listeners to the different properties of a conversation. The development and use of these linguistic means enable the child to establish different social roles in a narrative interaction. The findings are interpreted in terms of the child's social-communicative development from being a 'character' to becoming a 'narrator' and 'author' of the reported conversation in the narrative situation.

\section{INTRODUCTION}

How could a child talk about a conversation that she recently heard? She could reproduce the conversation verbatim and omit any references to the

[*] Versions of this paper have been presented as an MA thesis for the Department of Psychology, University of Chicago, at the 1994 Chicago Linguistic Society conference and also the 1994 Stanford Child Language Research Forum. This research was supported, in part, by a grant from the Spencer Foundation to T. Trabasso. I am especially grateful to Tom Trabasso and also to William Hanks, David McNeill and Nedim Nomer for their comments and criticisms. Esra Özyürek contributed to the data collection. Address for correspondence: Aslı Özyürek, Departments of Psychology and Linguistics, 5848 S. University Ave. Chicago IL60637, USA. E-mail: ozyu@midway.uchicago.edu 
speaker. This form of 'direct quotation' would make it difficult for a listener to identify who was speaking to whom. Or the child could orient the listener by indicating explicitly who said what to whom. She could also transform the dialogue into a narrative and add features other than speaker identity such as linguistic devices to interpret the nature of the conversational exchange. Thus, the child has a number of ways as to how she could talk about a conversation.

This study investigates these and other possible ways in which children report conversations in Turkish and examines how these reports change with age. The different ways of talking about conversations are important since they reflect the child's different stages of social-communicative development. That is, the child establishes different social roles and alignments in a narrative situation using different ways to talk about conversations.

\section{Linguistic devices for reporting conversations}

In order to talk about speech events the child needs to acquire and use several linguistic devices. Linguistic devices help the child to reorganize information in order to orient a listener to the relevant properties of a conversational exchange. The main linguistic device for reporting an utterance is a framing clause (e.g. $X$ said, '...') and its constituents. This study focuses on three constituents of a framing clause: (I) a proper noun or pronoun as subject (e.g. fohn said, '...' He said, '...'), (2) a verb of saying (e.g. Fohn said,) and (3) a

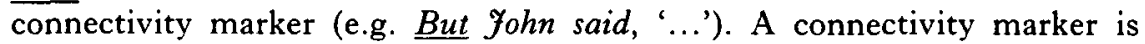
important if the frame is in a discourse because it marks explicitly the relationship between the adjacent utterances of two speakers.

The above analysis treats the organization of the reporting of a conversational discourse as a sequence of 'adjacent pairs of utterances' between two different speakers taking 'conversational turns' (Sacks, Schegloff \& Jefferson, 1974; Schegloff \& Sacks, 1973). That is, the linguistic devices serve to organize the reported discourse as exchanges of utterances between a speaker and an addressee. Therefore, the usage of these linguistic devices might help the child inform a listener about (I) what was said, (2) who said it and (3) what was the relationship between the two speakers' adjacent utterances in the conversational exchange.

The main linguistic devices for reporting what was said are unframed direct quotations (e.g. ' I want to go to the movies.'), framed direct quotations (e.g. Fohn said, 'I want to go to the movies.') and framed indirect quotations (e.g. Fohn said that he wanted to go the movies). To specify who said the utterance and to mark a conversational turn, proper names may be used as subject markers in the framing clause (e.g. Fohn said, '...', Mary said, '...'). 'To mark the relationship between two speakers' adjacent utterances, different kinds of verbs of saying may be used (e.g. Mary asked '...', fohn refused '...'). 


\section{TABLE I. Summary of linguistic devices used for reporting conversations}

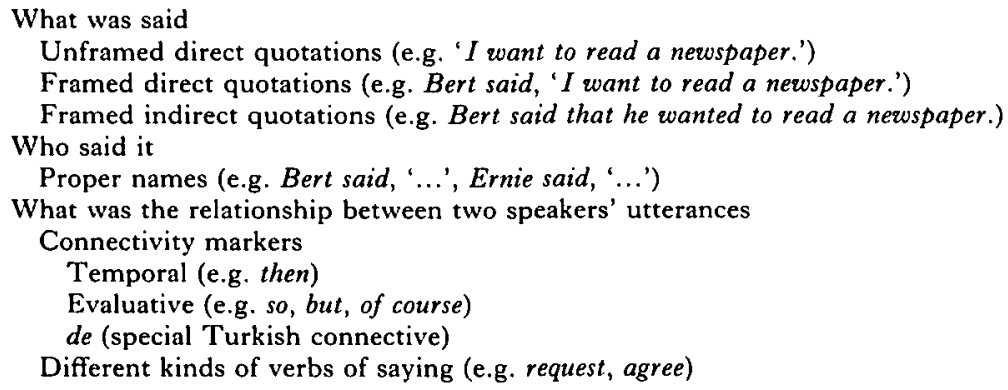

Finally temporal and evaluative connectivity markers in the framing clause (e.g. Then fohn said, '...' or However, Yohn answered, '...') serve as additional markers of the interpersonal properties of the conversational exchange. Table I gives a summary of the above linguistic devices used for reporting conversations.

\section{Theory and development of 'Character and Narrator roles' and 'Authorial Voice'}

Speakers with their ability to use these linguistic devices can express different social roles and alignments they take up to themselves and the others present in a communicative situation. For example, Goodwin (1990) has shown that 'he said, she said' confrontations are used in children's gossips and disputes as vehicles for organizing their social relationships.

Here, two kinds of notions about speakers' social roles and alignments in a communicative situation will be discussed; participant roles and authorial voice. The notion of 'participant roles' has been developed by Goffman ( 198 I) and by Hanks (r 991 ) as the alignments we take up to ourselves and the others as expressed in the way we manage the production of an utterance. For example in reporting utterances one speaker can shift between different participant roles. A speaker could align himself with quoted speaker, taking a CHARACTER ROLE or with narrator, taking a NARRATOR ROLE. For example in reporting an utterance in the form of a framed direct quotation (e.g. Then John said, 'Do you want to go to the store?') the speaker first aligns himself with the narrator in producing the framing clause (Then fohn said). Later in the production of the direct quotation the speaker aligns himself with the character as if he is talking as the quoted speaker ('Do you want to go to the store?'). Within the framework of this paper we will discuss the child's ability to take and shift between different participant roles, those of the character and narrator in the course of her reported discourse. 
Another important notion for social communicative competence is AUTHORIAL vOICE. Authorial voice in discourse has been formulated by Voloshinov (1973) as the attitude a speaker expresses towards his utterance. For example in their reports speakers mostly interpret what was said (e.g. Fohn insisted that Mary go to the store) instead of quoting the utterance verbatim (e.g. Fohn said, 'Mary, do you want to go to the store?'). According to Voloshinov indirect reported speech style is a powerful linguistic device for speakers to express their interpretation of the quoted utterances. Furthermore, the way the speaker interprets the other's speech also indexes his attitude towards what was said and assigns him an authorial voice in his discourse. In the example above the author reports John's utterance as 'insistence' rather than just a 'question' and thus expresses his attitude towards what John said. "The words and expressions incorporated into indirect discourse ... are made ... to accommodate the shadings of the author's attitude' (Voloshinov, 1973: I31). Therefore these notions about speaker's authorial voice as well as participant roles provide a framework for further analysis of a child's reported discourse.

The child's ability to establish these different social-communicative roles are reflected and intersect with their ability to use the linguistic devices listed above. The child first observes a conversation between a speaker and an addressee. Later, when the child reports the conversation she has to acquire linguistic devices that enable her to transpose the conversation into narration situation where she narrates the conversation to a listener. During the narration if the child reports the conversation as unframed directly quoted speech (e.g. 'Do you want to go the store?'), she aligns herself only with the quoted speakers and takes character role in her discourse. While this reporting style remains faithful to the original conversation and to what the quoted speakers said it fails to distinguish who said what for the listener of the report. However, as the child frames the utterances and marks who said what (e.g. Fohn said, '...') she aligns herself with another participant role, that is the narrator role. Now the child is able to shift between two different participant roles, narrator and character in her narrative discourse using different linguistic devices to report conversations.

The child's interpretation of the conversation situation assigns her an authorship in addition to her ability to express different participant roles. The child expresses her authorial voice by transforming and interpreting the original utterances in her reports. One device for expressing authorial voice is the use of framed indirect quotations. As noted above indirect speech allows authors to infiltrate and manipulate the authenticity of the quoted utterance. The style of indirect reporting transposes some aspects of the original utterance such as person, verb tense and deictics into those of the framing clause and in this way permits interpretation, at least minimally, by the child (Hickmann, I982). In addition authorial voice is expressed through 
the use of evaluative connectivity markers and different verbs of saying in the framing clauses. These devices reflect the child's interpretation of the interpersonal relations between the speaker and the addressee for the listener. To illustrate consider the following conversation and translation of a Turkish narration:

\section{Conversation}

(1) Bert: Do you know what I want Ernie? To read the paper.

Ernie: Then why don't you go to the store and get a newspaper?

Bert: No way!

\section{Narration}

(2) Bert says that he wants to read the paper. So Ernie forces him to get a newspaper from the store. Of course Bert refuses to go. (age, I $3 ;$ I)

In this example the child is using framed indirect quotations (Bert says that ..., Ernie forces him to ..., Bert refuses to ...), evaluative connectivity markers (so, of course) and verbs of saying (force, refuse). The child, in using these devices, assumes an authorial voice and expresses her attitude towards the speech event. The author's attitude is expressed through interpretation of what was said, how it was said and what was the nature of the exchange.

\section{Previous studies on children's reported discourse}

Goodell \& Sachs (1992) studied the acquisition of different reporting styles of English by children four to eight years of age. In particular, they investigated the use of framed direct (e.g. Yohn said, 'I want to go to the movies.') and framed indirect (e.g. Fohn said that he wanted to go to the movies.) quotations. They found that the use of the framed direct quotations increased linearly with age. However, indirect reporting style followed a U-shaped function: six-year olds displayed fewer correct indirect forms than did either four-or eight-year olds. They also found that the use of non-generic speech act verbs (e.g. explain, remark etc.) increased by age. Hickmann (1982, 1993) examined the developmental progression of reporting styles on the basis of the discourse organization. She studied unframed direct quotations (e.g. ' $I$ want to go to the movies.'), framed direct quotations (e.g. Fohn said, 'I want to go to the movies.'), framed indirect quotations (e.g. Fohn said that he wanted to go the movies.) and paraphrases of the original speech (e.g. Fohn wanted to go the movies.). The data indicated that four-year olds used unframed direct quotations in re-enactments or paraphrases of what they had heard throughout the discourse. In contrast, within the reported discourse seven- and ten-year olds initially used paraphrases but then they shifted to the use of framed direct reporting style. This shift was strongly demarcated in the reported discourse. Adults, in contrast, integrated framed direct and indirect reporting styles with paraphrases throughout their reports. Ely \& McCabe 
(1993) recently published two studies in a paper on spontaneous reports of past speech in children's personal narratives. The frequency of direct and indirect quotations rose with age (from I $; 2$ to $5 ; 2$ and from $4 ; 0$ to $9 ; 0$ ). Younger children used more indirect quotations when reporting the speech of others than they did their own speech. In addition they found that girls used reported speech more frequently than did boys and their quotations were more direct in form than were those of boys.

The focus of the above studies was on how children reported individual utterances. The present study investigates the development of reporting styles in the context of a conversational exchange. It investigates how the child's transformation of a series of utterances organizes the discourse as exchanges between a speaker and an addressee. Therefore, in this study reporting an adjacent pair of utterances uttered by two speakers becomes an important unit (e.g. Bert said, 'Go and get a newspaper.' However, Ernie refused.) The question here is: Does the child mark linguistically the exchanges between the speaker and the addressee in terms of agreementdisagreement, request-refusal or questioning-answering over the course of the reported dialogue? Furthermore, this study treats children's acquisition of reported discourse not only in terms of acquiring the reported speech forms but also as learning the requirements of the social-communicative context of reporting.

Given the linguistic devices for reporting conversations and the requirements of the social-communicative situation, one possible developmental sequence is as follows. Initially, the child might reproduce the spech of the others in the form of unframed quotations. Hickmann's (1993) results show that younger children use mostly unframed direct quotes in re-enactments. In another line of research on children's use of gesture and speech in narrative development, McNeill (1992) has shown that younger children's gestures that accompany their speech are essentially enactments. Therefore, initially, the child might report what she witnessed by aligning herself mostly with the quoted speakers. The child's participant role in this communicative situation, therefore, will be mostly that of a character.

However, quoting the utterances unframed will make it difficult for the listener to know who said what. As the child becomes aware of the need to orient the listener and the requirements of a communicative situation, she might begin to frame the utterances and mark conversational turns by speakers' names. Previous research (Hickmann, 1982, 1993; Goodell \& Sachs, I 992; Ely \& McCabe, I993) shows that the child's ability to frame direct quotations increases with age. Furthermore, marking the conversational turns by speakers' names might be acquired later since it requires the child to mark new information for the listener. In Turkish the subject NP is used if the sentence introduces new information and is usually dropped otherwise (Enc, 1986). Therefore, marking conversational turns by subject 
NPs is a special discourse device for Turkish children to learn. The child will gradually align herself with the narrator role learning to frame utterances with speakers' names in her reported discourse.

The next important developmental shift in the child's discourse we might expect is one that moves from reporting of others' speech to involvement of the self as an interpreter of what was said. Here the child transforms what was said into her interpretation by using indirect reported speech, evaluative connectivity markers and different kinds of verbs of saying. Again, the previous research (Hickmann, 1982, 1993; Ely \& McCabe, 1993) shows that children's use of indirect reporting style increases with age. We also expect Turkish children to use indirect forms much later because of the syntactic complexity of the indirect reported speech style in Turkish (Slobin, 1986). Furthermore Goodell \& Sachs ( I 992) note the late emergence of non-generic speech act verbs and this can delay the child's ability to evaluate the conversational exchange. The child becomes able to express her authorial voice in the reported discourse as the last stage of social-communicative development.

It is also important to note here that the development of these skills to talk about conversations indicates the child's developing metalinguistic capacity. Metalinguistic or the reflexive capacity of language consists of the use of language to speak about speech. What the above linguistic forms have in common is that their proper usage depends on the metalinguistic capacity of a speaker to monitor and express his relation to his ongoing speech. They are used for the effective expression of the speaker of his alignment or attitude towards his text. Therefore their development in the child's discourse indicates the child's developing metalinguistic capacity.

METHOD

\section{Subjects}

The subjects were 48 children, half of whom were boys. The subjects were distributed, 16 each, into three age groups with median ages of $5 ; 2,9 ; 4$, and I $3 ; 1$. Hereafter, the groups are referred to by the numerals 5,9 and 13 . All the subjects were monolingual, middle class, Turkish speaking children who attended summer schools in Istanbul, Turkey.

\section{Materials}

Each child saw a Sesame Street videotape of a Bert and Ernie dialogue, one minute in length. The dialogue is reproduced in Table 2. The dialogue below provided the subjects with the conversation situation (see Appendix for the original Turkish dialogue).

English translation of the Bert and Ernie dialogue:

I Ernie: Isn't it a boring day? 
2 Bert: Yes, you're right, Ernie.

3 E: It's so dull.

$4 \mathrm{~B}$ : Yes, it is an unpleasant day.

$5 \mathrm{E}: \mathrm{Mmmmm}$, I'm bored.

6 B: Yes me too. Do you know what I want Ernie? I want to read the paper.

7 E: Gee! That's a wonderful idea Bert!

$8 \mathrm{~B}:$ Isn't it?

$9 \mathrm{E}$ : So go to the store and buy a newspaper.

Io $B$ : No way!

II E: Why not Bert?

I 2 B: Because I went the other day. I also went the day before that.

I 3 E: That's right. You have always gone to the store.

I 4 B: That's why you will go to the store today, Ernie. Today is your turn to buy the newspaper.

I 5 E : O.K. All right Bert. Since you have been going to the store for the past few days, now it is my turn to go there. I will put on my scarf and leave immediately.

(Ernie puts his scarf on)

I6 B: Ernie excuse me but what are you going to do with the scarf? Look, the weather is very nice outside.

I $7 \mathrm{E}$ : Yes, it is very nice now but I can not be sure that it is not going to change. It might get cold suddenly. I have to be prepared.

I 8 B: O.K. then take your scarf Ernie.

I9 $\mathrm{E}:$ Where is the umbrella Bert?

$20 \mathrm{~B}$ : Umbrella! there is not a single cloud in the sky!

2 I E: But it might suddenly rain. I might get wet and catch a cold.

22 B: O.K. I left the umbrella over there.

${ }_{33}$ E: Thanks Bert.

\section{Instructions}

Each child was tested individually. The child was told that she would see a Bert and Ernie movie. Her task was to tell 'what happened in the movie' to a friend who was waiting outside. The child saw the videotape twice. Then the friend entered the room and the child was told to tell what happened in the movie. The retelling was audio taped.

\section{Coding}

Each child's reported conversation was parsed into sentences. Then each sentence was coded in terms of the linguistic devices used by children to inform their listener about (a) what was said, (b) who said it, (c) what was the relationship between two speakers' utterances in the conversational exchange. 
What was said. The main linguistic devices for reporting what was said are the previously discussed unframed direct quotations, framed direct quotations and framed indirect quotations. The examples given below illustrate the reporting styles in Turkish and in English in translation.

\section{Unframed direct quotation}

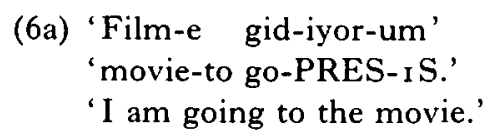

\section{Framed direct quotation}

(6b) ERNIE 'Film-e gid-iyor-um' DE-DI.

EDI 'movie-to go-PRES-IS' SAY-PAST.

ERNIE SAID, 'I am going to the movie.'

Turkish is a SOV language and has a relatively flexible word order. In framed direct quotations the subject (Edi 'Ernie') of the framing clause is usually placed before the quoted utterance and the verb of saying (dedi 'said') follows the quote.

\section{Framed indirect quotation}

(6c) Edi film-e git-TIG-I-NI SOYLE-di

Ernie movie-to go-NOM-3S: POSS-ACC TELL-PAST.

Ernie TOLD OF HIS GOING to the movie.

Ernie said that he was going to the movie.

In Turkish, a framed indirect quotation is marked by a verb of saying soyledi 'told'. Indirect quotation also transforms the original utterance into a noun-phrase (e.g. Ernie told of his going to the movie.). In this case the original utterance is transformed into either a nominalization or a verbal noun. In contructing nominalizations, the suffix (-DIK) replaces the tense suffix (except for future tense) of the original verb; and also a possessive $(-I)$ and an accusative suffix (-nI) are added to the verb (see (6c)). The verbal nouns are constructed in the same way except that in this case the suffixes $(-\mathrm{mEg}),(-\mathrm{mE})$ and $((\mathrm{y}) \mathrm{Is})$ replace the tense suffix of the verb. The differences in the usage of verbal nouns vs. nominalizations in Turkish reporting speech forms are discussed in Underhill (1976).

Who said it. To specify who said the utterance and to mark a conversational turn, proper names may be used as subject markers in the framing clause (e.g. fohn said, '...', Mary said, '...'). An example of the use of proper names in Turkish framing clauses is given below:

(7a) Budu '...' de-di. EDI '...' de-di.

BERT '...' say-PAST. ERNIE '...' say-PAST

BERT said, '...' ERNIE said, '...' 


\section{ÖZY ÜREK}

In Turkish, the use of proper names especially marks the conversational turns because their usage contrasts with other types of framing clauses where the subject NP is dropped. In Turkish leaving out the NP argument entirely is allowed. Enc (1986) argues that if the subject NP is dropped then the sentence is identified as a comment on the topic expressed by the previous sentence. On the other hand if the subject NP is used then the sentence must introduce new information. In the reports of conversations, therefore, the use of speakers' proper names as subject NPs must serve the function of marking a conversational turn. This usage marks new information for the listener. (contrast (2a) with (2b)):

(7b) EDI '...' de-di. $\emptyset$ '...' de-di.

ERNIE '...' say-PAST. $\emptyset$ '...' say-PAST

ERNIE said, '...' (HE) said '...'

The relationship between two speakers' utterances in the conversational exchange. In reporting conversations, the relationship between the two speakers can be marked using different kinds of connectivity markers and verbs of saying.

Turkish has a special connective $d e$ that is frequently used in reporting conversations. The closest translation of this connective into English could be 'in turn'. It is used for pairing two speakers' utterances that form an adjacency pair in the original conversation. It is placed after the proper name in the framing clause of the second speaker's quote:

(8) Budu 'Cok sikici bir gun' de-di. Edi DE 'Evet' de-di.

Bert 'Very boring a day' say-PAST. Ernie IN TURN 'yes' say-PAST

Bert said, 'It is a very boring day.' Ernie, IN TURN, said, 'Yes'.

In addition temporal and evaluative connectivity markers in the framing clause (e.g. Then Fohn said '...' or However, Fohn answered, '...') serve as markers of the nature of the adjacency pair in terms of agreementdisagreement, request-refusal or questioning-answering relations. A typical usage of the connectivity markers in Turkish is shown in the example below:

(9) Budu '...' de-di. Ama Edi '...' de-di.

Bert '...' say-PAST. BuT Ernie '...' say-PAST

Bert said, '...' But Ernie said, '...'

Finally non-generic verbs of saying may be used. (e.g. Mary asked '...'; Yohn refused) instead of the generic ones (e.g. say) to further mark the interpersonal properties of the conversational exchange.

\section{Reliability}

Forty per cent of all the narrations were randomly selected and independently coded by two native speakers of Turkish. Each child's narrative was parsed into sentences and the kappa coefficient for the sentence boundaries was 
$90 \%$. The kappa coefficients for coding 'what was said' (unframed direct, framed direct or framed indirect quotation), and 'who said it' (use of proper names) were $9 \mathrm{I} \%$ and $93 \%$ respectively. Lastly the kappa coefficients for coding 'the relationship between the two speakers' utterances' were $85 \%$ for categories of connectivity markers and $83 \%$ for verbs of saying.

\section{RESULTS}

The data are organized into two main parts. In the first, the representative reports by children from each age group are presented to indicate how the children talked about the conversation they observed. In the second part, the statistical age comparisons based on the quantification of the coded reports are presented.

\section{Representative retellings by age}

The representative retellings by children from each age groups are presented to characterize each group's typical reporting style.

Five-year olds. Children in this age group used unframed direct quotations half of the time to report the conversational situation. When the five-year olds framed the utterances in their narrations they did so by only using the verb of saying and omitting the speaker's name in the framing clause, (e.g. $\emptyset$ '...' dedi 'said'). Turkish allows one to construct such sentences where the subject NP can be left out entirely as discussed above. Note that this style of reporting does not mark the conversational turns or the relationship between the two speakers' utterances for the listener. A representative example is as follows (the conversational turns are marked by double slash):

\section{Example (Ayse, 5;2)}

(3) 'Canim cok sikiliyor.' // 'Benim de.' // 'Gazete okumak isterim.' // 'Bay Z'nin dukkanindan gazete al.' // 'Nicin?' // 'Cunku hep ben aliyorum. Ertesi gun de ben almistim. Ondan onceki gun de ben almistim.' // 'Aaa dogru. Atkimi aliyim' dedi. // 'Bir tane bile bulut yok' dedi. // 'Ama her an firtina olabilir. Ben de islanip usutebilirim.' dedi. 'Her seyi aldim. Semsiyem nerde?' dedi. // 'Ordaki dolapta.' dedi.

\section{Literal Translation}

'I'm bored.' // 'Me, too.' // 'I want to read the paper.' // 'Get a newspaper from Mr Z's store.' // 'Why?' // 'Because I always buy it. I bought it the other day. I also bought the day before that.' // 'That's right. 
I will put on my scarf.' // (He) said, 'There is not a single cloud in the sky.' // 'But it might rain. I might get wet and catch a cold. I got everything.' (He) said, 'Where is my umbrella?' // (He) said, 'It is in the closet over there.'

Nine-year olds. In contrast to the five-year olds, the nine-year olds typically framed the quotations (e.g. Edi 'Cok hareketsiz bir gun' dedi. Ernie said, 'This is a boring day.'). In contrast to five-year olds, children in this age group included speakers' names as subjects in the framing clauses to mark conversational turns. They also used a specific connectivity marker that is unique to Turkish, (de 'in turn') to mark the adjacency pairs.

\section{Example (Cem, 9;5)}

(4) Edi 'Cok hareketsiz bir gun' dedi. Budu de 'Evet' dedi. Budu 'En iyi fikir gazete okumak' dedi. Edi de 'Evet, oyle' dedi. 'Cok iyi bir fikir' dedi. 'Hadi Budu, sen gidip Bay Z'nin dukkanindan bir gazete alip gelir misin?' dedi. Budu de 'Hayir, olmaz' dedi. 'Cunku ben dun, dunden onceki gun ve ondan onceki gun de ben gitmistim.' dedi. 'Bugun sira sende' dedi. Edi de 'Evet, bugun sira bende' dedi. 'Atkimi alip gidiyim' dedi. Budu 'Atkini ne yapacaksin?' dedi. 'Hava cok guzel. Neden atkini alacaksin?' dedi. Edi de 'Ama aniden firtina cikabilir ve ben islanip usutebilirim' dedi. 'Tamam' dedi. Sonra 'Semsiyeyi alabilir miyim?' dedi. 'Semsiyeyi ne yapacaksin? Havada bir bulut bile yok' dedi. Edi de 'Ama aniden bulutlar gelip yagmur yagabilir, usutebilirim' dedi.

\section{Literal Translation}

Ernie said, 'This is a boring day.' Bert, in turn, said, 'Yes.' Bert said, 'Reading the paper is a good idea.' Ernie, in turn, said, 'Yes, that's right.' (He) said, 'That's a wonderful idea.' (He) said, 'Bert, would you go and get a newspaper from the store?' Bert, in turn, said, 'No way!' (He) said,

'Because, I went the other day and also the day before that.' (He) said, 'Today is your turn.' Ernie, in turn, said, 'Yes, today is my turn to go.' (He) said, 'I will put on my scarf and leave.' Bert said, 'What are you going to do with the scarf?' (He) said, 'The weather is very nice. Why are you taking your scarf?' Ernie, in turn, said, 'It might suddenly rain and I might catch a cold.' (He) said, 'O.K.' Then (he) said, 'May I get the umbrella?' 'What are you going to do with the umbrella?' (He) said, 'There is not even one cloud in the sky.' Ernie, in turn, said, 'But the clouds might come, it might rain and I might catch a cold.'

Thirteen-year olds. In contrast, the thirteen-year olds used a substantial amount of framed indirect quotations (e.g. Ernie gunun cok sikici oldugunu 
soyledi. 'Ernie said that it was a boring day'). They used a variety of evaluative connectivity markers (e.g. so, but) and different kinds of verbs of saying (e.g. agree, refuse) in the framing clauses. Therefore, children of this group in addition to marking conversational turns and adjacency pairs marked the conversational exchange in terms of agreement-disagreement, antecedent-consequence, request-refusal, or questioning-answering relations for the listener.

\section{Example (Murat, 13; 1)}

(5) Edi gunun cok sikici oldugunu soyledi. Budu de ona hak verdi. Sonra Budu caninin gazete okumak istedigini soyledi. Bunun uzerine Edi ona Bay Z'nin dukkanina gidip gazete almasini soyledi. Ama Budu, bunu kendisinin yapmiyacagini cunku dun ve daha onceki gun kendisinin gazete aldigini soyledi. Sonra Edi'nin gazete almasini istedi. Edi de 'tamam' dedi. Ondan sonra 'atkimi alip gidiyim' dedi. Tabii Budu de atkisini neden aldigini sordu. 'Hava cunku cok sicak.' dedi. Edi de, iste, 'Her an bir firtina cikabilir' dedi. Sonra Budu 'Tamam atkini alip git' dedi. Bu sefer de Edi iste semsiyesini almak istedi. Gene semsiyesini neden almak istedigini sordu. 'Cunku havada tek damla bile bulut yok' dedi. Edi de her an bir firtina cikip firtinadan zarar gorebilecegini soyledi. Budu de semsiyenin dolapta oldugunu soyledi. Edi de semsiyeyi almaga gitti.

\section{Literal translation}

'Ernie said that it was a very boring day. Bert agreed with him. Then Bert said that he wanted to read the paper. So, Ernie told him to go to Mr. Z's store and buy a newspaper. But, Bert said that he was not going to do it because he bought the newspaper yesterday and also the day before that. Then (he) asked Ernie to get the newspaper. Ernie said, 'O.K.' Then (he) said, 'I will take put on my scarf and leave.' Of course Bert, in turn, asked him why he put on a scarf. ( $\mathrm{He}$ ) said, 'The weather is very hot outside.' Ernie, in turn, said, 'It might suddenly rain.' Then Bert said, 'O.K., get your scarf and leave.' This time Ernie wanted to get an umbrella. Again Bert asked him why he wanted to take an umbrella. (He) said, 'There is not a single cloud in the sky.' Ernie told him that he could always be harmed by the rain. Bert told him that the umbrella was in the closet. Ernie went to get the umbrella.'

\section{Quantitative analysis}

The distribution of the linguistic devices across three age groups is presented below. 


\section{ÖZY ÜREK}

What was said. The mean proportions of sentences with unframed direct quotations, framed direct quotations and framed indirect quotations in three age groups are given in Table 2.

TABLE 2. Proportions of unframed direct quotations, framed direct quotations, framed indirect quotations according to age

\begin{tabular}{ccccc}
\hline Age group & $\begin{array}{c}\text { Unframed } \\
\text { direct } \\
\text { quotations }\end{array}$ & $\begin{array}{c}\text { Framed direct } \\
\text { quotations }\end{array}$ & $\begin{array}{c}\text { Framed indirect } \\
\text { quotations }\end{array}$ & $\begin{array}{c}\text { Total number of } \\
\text { unframed and } \\
\text { framed } \\
\text { quotations }\end{array}$ \\
\hline 5 & 0.52 & 0.49 & 0 & 243 \\
9 & 0.07 & 0.89 & 0.04 & 247 \\
13 & 0.09 & 0.58 & 0.35 & 218 \\
\hline
\end{tabular}

A one-way analysis of variance on the proportions of unframed quotations indicates that there was a significant age effect $F(2,45)=13.44, p<0.01$. Individual comparisons $p<0.01$ showed that the five-year olds used proportionately more unframed quotations than either of the two older groups. For the framed direct quotations, a similar analysis also yielded a significant age effect $F(2,45)=10.34, p<0.01$. Individual comparisons showed significant differences between the nine-year olds and the other two groups. Framed direct quotations were used the most by nine-year olds. Lastly, thirteen-year olds favoured framed indirect quotations more than the other groups in their reports. A one-way analysis of variance again indicated a significant age effect, $F(2,45)=17.98, p<0.01$. Individual comparisons $p<0.01$ showed that the thirteen-year olds differed significantly from the other groups.

The data in Table 2 also allow comparisons in how each age group distributed their reporting styles. The five-year olds framed the utterances half of the time. For nine-year olds, quotations were nearly always framed. While thirteen-year olds' quotations also were framed, they reported a substantial number of indirect quotations where the aspects of the original utterance were transformed to nominalizations or verbal nouns.

Who said it. The mean proportions of conversational turns marked by the speakers' proper names (e.g. Bert said '...', Ernie said '...') are given below in Table 3. To assess the mean proportions, the number of turns marked with proper names in the framing clauses were divided by the total number of turns where framing clauses were used.

The results, $F(2,45)=\mathrm{I} 6.6, p<0.0 \mathrm{I}$, indicated a significant age effect. Individual comparisons $p<0.01$ showed that five-year olds rarely marked the conversational turns with speakers' names. That is, children in this age group when they framed the utterances in their narrations they did so by using only the verb of saying and omitting the speaker's name (e.g. $\emptyset^{\prime} . .$. 'dedi). They did 
TABLE 3. Proportion of conversational turns marked with speakers' names according to age

\begin{tabular}{ccc}
\hline Age group & $\begin{array}{c}\text { Conversational turns } \\
\text { marked with speakers' } \\
\text { names in framing clauses }\end{array}$ & $\begin{array}{c}\text { Total number of } \\
\text { conversational turns } \\
\text { with framing clauses }\end{array}$ \\
\hline 5 & 0.34 & 62 \\
9 & 0.77 & 124 \\
13 & 0.76 & 172 \\
\hline
\end{tabular}

not indicate to their listeners who said what. Whereas nine- and thirteen-year olds marked conversational turns using speaker names very frequently in their reports.

What was the relationship between the two speakers' utterances? 'Table 4 lays out the mean proportions of different connectivity markers (temporal, Turkish connective de and evaluative forms) used in the framing clauses to mark the conversational exchange in different age groups.

TABLE 4. Proportion of conversational turns marked with different connectivity markers according to age

\begin{tabular}{rcccc}
\hline Age group & $\begin{array}{c}\text { Conversational } \\
\text { turns with } \\
\text { temporal markers }\end{array}$ & $\begin{array}{c}\text { Conversational } \\
\text { turns with } d e\end{array}$ & $\begin{array}{c}\text { Conversational } \\
\text { turns with } \\
\text { evaluative markers }\end{array}$ & $\begin{array}{c}\text { Total number of } \\
\text { conversational } \\
\text { turns }\end{array}$ \\
\hline 5 & 0.16 & 0.10 & 0 & 149 \\
9 & 0.20 & 0.40 & 0.05 & 178 \\
13 & 0.15 & 0.38 & 0.13 & 167 \\
\hline
\end{tabular}

Table 4 shows that all the age groups used temporal markers (e.g. then, again) in nearly equal proportions. The results showed that the groups did not differ significantly in terms of their usage of temporal markers.

However, the special Turkish connective $d e$ ' in turn' was favoured by nineand thirteen-year olds more than by the five-year olds, $F(2,45)=14.845, p$ $<0.01$. The differences between the older two groups and the younger group was supported by individual comparisons, $p<0.01$. The two older groups marked the turn changes for the listeners consistently. Children used this device in addition to proper names to mark conversational turns. It is used for pairing two speakers' utterances that form an adjacency pair in the original conversation. This device allows children of ages nine and thirteen years to organize their reports as pairings of utterances for their listeners. Thus, the use of this device assigns them a narrator role.

Lastly, for the evaluative markers (so, but etc.) the youngest group did not use any evaluative forms but then usage begins in the second and third age 
groups $F(2,45)=13,99, p<0.01$, and by individual comparisons $p<0.01$. The evaluative markers were favoured by the thirteen-year olds the most. This allowed the oldest group to interpret the observed conversational exchanges in terms of agreement-disagreement, request-refusal or antecedent-consequence relations. That is, thirteen-year olds were the most efficient in interpreting the original utterances in terms of their interpersonal properties.

The data in Table 4 also allow comparisons of how each age group distributed their use of different connectivity markers in their reports. The five-year olds used mostly temporal markers and also the Turkish connective $d e$ to a lesser extent. They did not use any evaluative markers. Nine-year olds used the Turkish connective more than the temporal markers. This group although infrequent began using some evaluative connectivity markers. Lastly the thirteen-year olds used the connective de most of the time and also a substantial number of evaluative markers.

Figure I illustrates each age group's preference for verbs of saying to mark the relationship in the conversational exchange. As mentioned before in fiveyear olds' reports, half of the utterances were unframed direct quotes $(0.52)$, that is used without any verb of saying. In contrast, in the nine- and thirteenyear olds' reports the proportion of the unframed quotes were only $(0.07)$ and $(0.09)$ respectively. For the reports that framed the quoted utterances the mean proportions were calculated for the generic verbs of saying (dedi 'said', and soyledi 'told') and for non-generic verbs (ask, agree, etc.).

For the generic verbs of saying, a one-way analysis of variance showed that the five-year olds used a significantly lower proportion than the other two groups, $F(2,45)=12^{\prime} \cdot 42, p<0.01$. For the non-generic verbs of saying, there was an increasing developmental trend, $F(2,45)=1176, p<0 \cdot 01$. There was difference between proportions of the nine-year olds and the 5-year olds as well as between nine-year olds and thirteen-year olds. Each was significant by individual comparisons, $p<0.01$. Nine-year olds included a small proportion (0.05) of non-generic verbs in their reports while five-year olds preferred only to use generic verbs. However, nine-year olds used fewer nongeneric verbs than the thirteen-year olds ( 0.14$)$ who marked the relationship in the conversational exchange more than the other two groups. This allowed thirteen-year olds to interpret the utterances in terms of their relations in the conversational exchange more than did the other two groups.

The main findings of the present study therefore follow a clear developmental sequence. The five-year olds used substantially more unframed quotations than did the older age groups. When the five-year olds framed the utterances they did so by using only a verb of saying and omitting the speaker's name in the framing clause. Finally five-year olds used primarily the generic verb of saying dedi 'said'. In contrast, nine-year olds typically framed the direct quotations and marked conversational turns by using proper names 


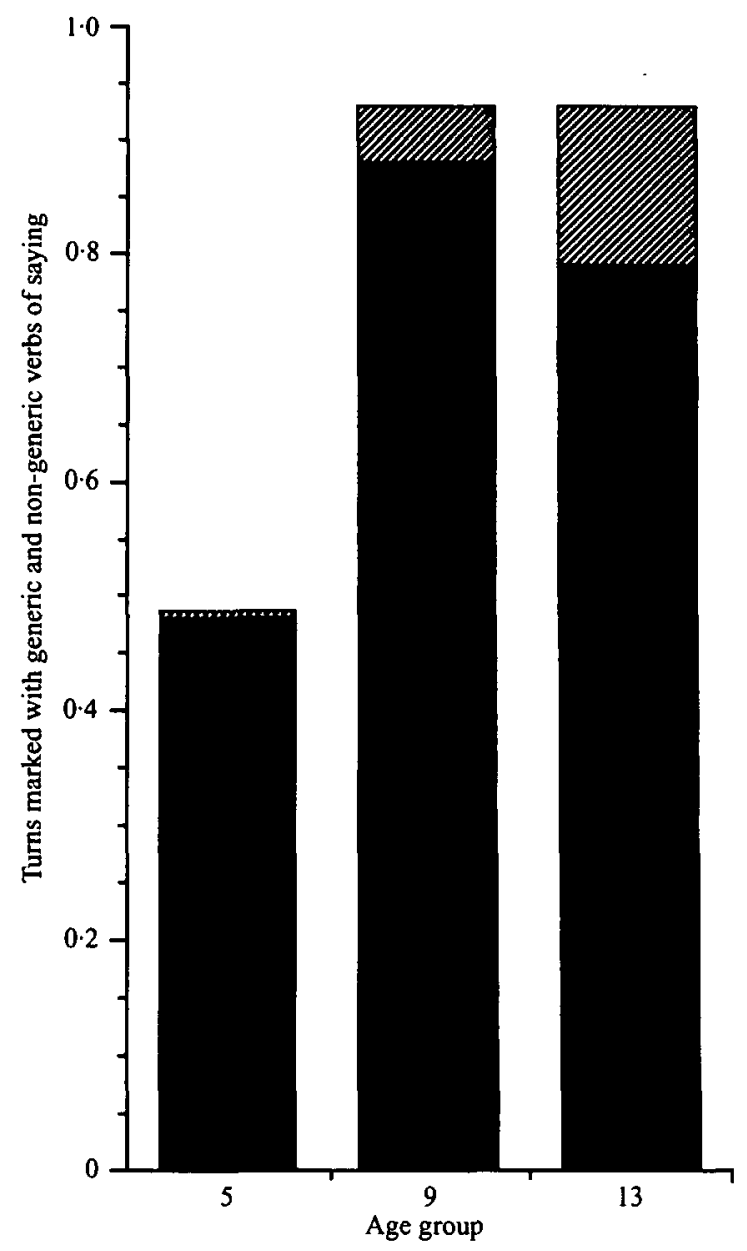

Fig. I. The mean proportions of conversational turns with the generic (w) and the nongeneric ( $\boldsymbol{\square}$ ) verbs of saying according to each age group.

nearly three quarters of the time. They used the Turkish connectivity marker $d e$ as the typical marker to connect adjacent pair of utterances. The majority of utterances reported by thirteen-year olds were framed direct quotations but they also used a substantial number of framed indirect quotations. They also used evaluative connectivity markers and different verbs of saying slightly more than nine-year olds.

\section{DISCUSSION}

Stages of social communicative development. These data show that children when reporting conversations initially talk about what was said, at a later 


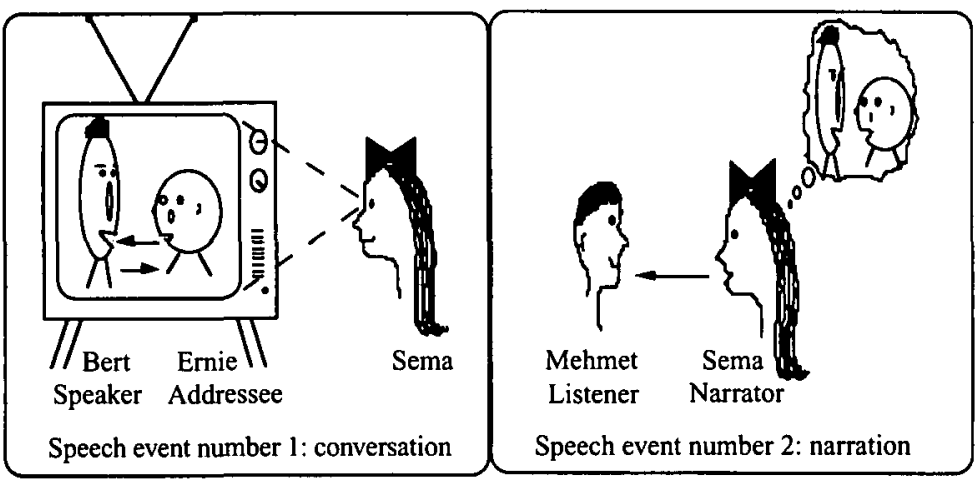

Fig. 2. Conversation and narration situation.

stage mark conversational turns and who said it and eventually interpret the content of the adjacency pairs. These results can be furthermore interpreted theoretically in terms of the relation between the development of social roles introduced earlier (Voloshinov, 1973; Goffman, 1981; Hanks, 1990), and the linguistic devices used to transpose conversation situation to narration situation. To understand graphically the distinction between the conversation and narration situation please refer to Figure 2.

Figure 2 displays speech event number $\mathrm{I}$ as the conversation situation when a child, Sema watches the conversation between Bert and Ernie (speaker or addressee). Speech event number 2, on the right depicts the narration situation when the child Sema narrates the conversation to a listener, Mehmet. The narration situation is between a narrator, Sema and a listener, Mehmet. This situation 'transposes' (Hanks, 1990) a conversation situation between two speakers (Bert and Ernie) from its time and place to that of the narration. The linguistic devices enable the differentiation of Sema's role as character or narrator and her authorial voice in the narration situation as distinct from the roles and voices of the speakers (Bert and Ernie) in the conversation situation.

Five-year olds reproduce the speech of others merely aligning themselves with the characters without further differentiation of a narrator role. This lack of differentiation of roles makes it difficult for the listener, Mehmet to know who said what. As Sema becomes aware of the need to orient the listener, she begins to assume the narrator role. Nine-year olds can express the narrator role by framing the speakers' utterances and marking conversational turns. Once the narrator differentiates speakers' roles as those of Bert and Ernie, the next developmental shift is one that moves from reporting of other's speech to involvement of the self as an author and interpreter of what was said. Here Sema evaluates Bert and Ernie's utterances and the interaction between them by using indirect reported speech, evaluative connectivity markers and non-generic verbs of saying. Sema, as a 
thirteen-year old narrator, can now express her attitude through an authorial voice towards Bert's and Ernie's utterances and the relationship between them. Sema gradually becomes the character, the narrator, and the author of the reported conversation in the narrative situation.

Comparisons with previous studies. The present findings are both similar and different with respect to previous developmental studies on the acquisition of reporting individual utterances. With regard to the increase in the use of framed direct quotations by age, our findings were similar to previous research (Hickmann, 1982, 1993; Goodell \& Sachs, I992; Ely \& McCabe, I993). However, in terms of the acquisition of framed indirect reported speech our results did not indicate a $U$-shape function as Goodell \& Sachs ( 1992 ) found. Rather there was an abrupt increase in the use of indirect framed quotations in the thirteen-year olds' narrations compared to those of the nine-year olds. Moreover, in the present study, the frequent use of framed indirect quotations appeared much later, at age 13, than the age reported both by Goodell \& Sachs (1992) and Ely \& McCabe (1993) (around ages $6-8$ ). This discrepancy may be explained by language differences. In Turkish, a framed indirect quotation includes the original utterance as a noun phrase (e.g. Ernie told of his going to the movie.). In this case, the original utterance is transformed into a nominalization or a verbal noun. This type of construction might create difficulty in mastery and could account for its appearance later in the Turkish data. The late acquisition of this type of construction by Turkish children has also been noted by Slobin (1986).

In addition the present findings revealed a developmental increase in the use of linguistic devices that organize children's reporting of conversational exchanges between a speaker and an addressee. The findings about this aspect of talking about conversations are unique to the present study. Furthermore some of the findings are specific to the Turkish language. The use of subject NPs and the special connective de to mark conversational turns are specific to Turkish discourse organization. The findings show that they have to be learned by children as the conventional communicative form of their specific language. The children have learnt to use the subject NPs in order to mark new information, in our case a conversational turn. Moreover the emergence of de earlier than the evaluative connectives suggest that it might be an unmarked linguistic device used to report conversations.

Another interesting finding our results show is that even though children did identify speakers and interpret reported speech more frequently as they got older, they did not do so always. This variation in the use of linguistic devices in the oldest children's discourse can be explained by their sensitivity to content of the adjacency pairs they were reporting. For example, the $89 \%$ of the conversational turns that were not identified by speakers' names were the second part of a question-answer adjacency pair (e.g., Bert said, 'Why are you taking your scarf?' ( $\mathrm{He}$ ) said, 'It might suddenly rain.'). The children 
might have learned that the second part of a question-answer pair presupposes a conversational turn and does not need to be further marked for the listener. Also $85 \%$ of the adjacency pairs that children interpreted consisted of request-refusal or agreement-disagreement rather than question-answer relations. This shows that children were sensitive to the content of the conversational interaction for their interpretation even though they did not interpret every exchange. However, the stimulus dialogue used did not contain many conflicts or disagreements which might explain why older children did not use evaluations to a larger extent in their reports.

Lastly the Ely and McCabe (1993) study shows that analysing personal reports reveals children's choice of different linguistic devices to talk about conversations. They have shown that the choice of the reported speech form is sensitive to the social, situational elements in the original conversation situation (e.g. self vs. other, gender) when the reports are personal narratives. These findings point to the need to study the child as a participant as well as an observer of the conversation situation. However, Ely \& McCabe (I 993) also noted that one does not have a way of knowing to what degree the children's reports of the conversation situation in their personal narratives were accurate. It is possible that the reports may have never been used in the original conversation or were used but transformed by the child in the narration situation. Knowing the original conversation situation allows one to analyse children's reports against what actually was uttered.

Finally, further work is needed to contribute to our understanding of children's reported speech phenomena in the narration context. For example, the identity and status (e.g. mother, father or a stranger) of the listener as well as the speaker may affect the way children report speech. Moreover children might also develop a sensitivity to the genre of the reported discourse (e.g. report told as a joke or a memory task) (Wade \& Clark, I993) as a communicative skill. Children's development of reporting skills can interact with multiple social-communicative requirements of the narrative situation that need to be investigated.

\section{CONCLUSION}

The present study tried to reveal how children learn to use the appropriate linguistic devices to orient their listeners to the appropriate aspects of conversational exchanges. These findings are in support of the suggestion that when children are learning to narrate they are all learning about the requirements of narration as a conventional communicative form (Bamberg, 1986; Cassell, 1991). The findings also revealed that children have to learn the appropriate devices of their own language for discourse organization. The study of how the linguistic devices are used by children to report conversational exchanges also helps us to understand further the development of social-communicative competence. These devices index the dispositions of 
the participants in the narrative situation, e.g. Sema speaking as one of the characters, the narrator, or the author and Mehmet as listener. The possible ways in which children talk about conversations therefore reflect their development as social actors with language who are '... actively engaged in the construction of their social worlds.' (Goodwin, I 990: 283).

\section{REFERENCES}

Bamberg, M. (1986). The acquisition of narratives, learning to use language. Berlin: Mouton de Gruyter.

Cassell, J. (1991). The development of the expression of time and event in narrative, Unpublished Ph.D. thesis, University of Chicago.

Ely, R. \& McCabe, A. (1993). Remembered voices. Journal of Child Language 20, 671-96.

Enc, M. (1986). Topic switching and pronominal subjects in Turkish. In D. I. Slobin \& K. Zimmer (eds), Studies in Turkish linguistics. Amsterdam: John Benjamins.

Goffman, E. (1981). Forms of talk. Philadelphia: University of Pennsylvania Press.

Goodell, E. W. \& Sachs, J. (1992). Direct and indirect speech in children's retold narratives. Discourse Processes I5, 395-422.

Goodwin, H. M. (1990). He-said-she-said. Talk as social organization among black children. Bloomington, IN : Indiana University Press.

Hanks, W. F. (1990). Referential practice : language and lived space among the Maya. Chicago: University of Chicago Press.

Hickmann, M. (1982). Metapragmatics in child language. In E. Mertz \& R. Parmentier (eds), Semiotic mediation: psychological and sociocultural perspectives. Orlando, FL: Academic Press.

- (r993). The boundaries of reported speech in narrative discourse: some developmental aspects. In J. A. Lucy (eds), Reflexive language: reported speech and metapragmatics. Cambridge: Cambridge University Press.

McNeill, D. (1992). Hand and Mind. Chicago: University of Chicago Press.

Sacks, H., Schegloff, E. A. \& Jefferson, G. (1974). A symplistic systimatics for the organization of turn-taking in conversation. Language 50, 696-735.

Schegloff, E. A. \& Sacks, H. (1973). Opening up closings. Semiotica 7 (4), 289-327.

Slobin, D. I. (1986). The acquisition and use of relative clauses in Turkic and Indo-European languages. In D. I. Slobin \& K. Zimmer (eds), Studies in Turkish linguistics. Amsterdm: John Benjamins.

Underhill, R. (1976). Turkish grammar. Cambridge, MA: MIT Press.

Voloshinov, V. (1973). Marxism and the philosophy of language. L. Matejka and I. Titunik (trans). Cambridge, MA: Harvard University Press.

Wade, E. \& Clark, H. (1993). Reproduction and Demonstration in Quotations. Journal of Memory and Language 32 (5).

\section{APPENDIX}

The original version of the Bert (Budu) and Ernie (Edi) dialogue in Turkish:

I Edi: Budu, ne kadar sikici bir gun degil mi?

2 Budu: Dogru, haklisin Edi.

3 E: Fazlasiyla sakin.

4 B : Evet, cok tatsiz bir gun.

5 E: $\quad$ Mmmm, canim sikildi.

6 B : Benim de. Aslinda benim canim ne istiyor biliyor musun

Edi? Gazete okumak. 


\section{ÖZY ÜREK}

7 E: Hey! Bu harika bir fikir.

$8 \mathrm{~B}$ : Degil mi ?

9 E: Hadi oyleyse bakkala gidip, bir gazete alip geliver.

Io B: Olmaaz!

I I E: Neden olmaz Budu?

I 2 B: Cunku dun de ben gittim. Daha onceki gun de ben gittim.

I3 E: Dogru, haklisin. Kac gundur hep sen gidiyorsun.

I 4 B : O yuzden Edi, bugun bakkala sen gideceksin. Bakkaldan gazete alma sirasi senin.

I 5 E: Oldu. Tamam Budu. Hergun sen gittigne gore simdi benim siram. Atkimi alip gidiyim hemen.

(Atkisini takiyor)

I6 B: Edi affedersin ama atkiyi ne yapicaksin? Baksana disarda hava cok guzel.

I 7 E: Evet simdi cok guzel ama degismiyeceginden emin olamayiz. Birden soguyabilir. Hazirlikli olmaliyim.

I 8 B: Iyi oyleyse atkini al Edi.

19 E: Semsiye nerde Budu.

$20 \mathrm{~B}$ : Semsiye mi? Havada bir tane bile bulut yok.

2 I E: Ama birden firtina cikabilir, islanabilir ve usutebilirim.

22 B: Peki semsiyeyi oraya koydum.

23 E: Tesekkurler Budu. 